\title{
TARIK ULUR ISLAM DAN DASAR NEGARA
}

\author{
Imam Amrusi Jailani \\ Fakultas Syariah IAIN Sunan Ampel Surabaya, alumni S-3 UIN Syarif Hidayatullah \\ Jakarta
}

\begin{abstract}
Abstrak: Tulisan ini ini akan menggambarkan moment-moment bersejarah dalam perjalanan bangsa Indonesia menjelang dan sesaat setelah proklamasi kemerdekaan. Dua golongan yang sama-sama berpengaruh saling berkompetisi dalam menentukan dasar Negara. Pertama, adalah golongan nasionalis "sekuler" yang memandang bahwa Negara yang akan didirikan (Republik Indonesia) harus berdasarkan kebangsaan, bukan Islam, dengan alasan tidak seluruh rakyat Indonesia beragama Islam. Sementara itu, golongan kedua, golongan Islam berpandangan bahwa dasar Negara dari bangsa Indonesia harus Islam, dengan alasan bahwa mayoritas rakyat Indonesia beragama Islam. Walaupun mayoritas tim perumus yang tergabung dalam keanggotaan Panitia Persiapan Kemerdekaan Indonesia (PPKI) adalah muslim, namun pada akhirnya dicapai kesepakatan dasar Negara republik Indonesia adalah Pancasila. Hal tersebut bukanlah merupakan sesuatu yang taken for granted, melainkan dicapai melalui proses diskusi yang panjang sejak pra kemerdekaan hingga pasca kemerdekaan. Kenyataan di atas memberikan gambaran perihal jiwa besar para elit atau tokoh muslim yang tergabung dalam keanggotan PPKI dengan menerima Pancasila sebagai dasar Negara Republik Indonesia yang baru saja diproklamasikan. Bagi mereka, kepentingan bangsa dan Negara di atas segala-galanya. Keutuhan bangsa dan Negara harus tetap diperhatikan dengan selalu menjaga kesatuan dan persatuan bangsa. Kepentingan seperti itu harus selalu dikedepankan dari pada kepentingan golongan, apalagi interes pribadi. Para pendiri republik ini telah memberikan teladan yang sebaik-baiknya untuk dikenang dan dicontoh oleh generasi berikutnya.
\end{abstract}

Kata Kunci: Islam, nasionalis, dasar negara, dan Pancasila 


\section{Pendahuluan}

Dalam konteks historis bangsa Indonesia -- menjelang diproklamirkannya kemerdekaan Negara Indonesia -- dikenal adanya dua kelompok yang saling berkompetisi dalam diskursus politik Indonesia; golongan Islam dan golongan nasionalis. ${ }^{1}$ Kedua kelompok tersebut sama-sama mencurahkan segenap perhatian dan pikirannya untuk mempersiapkan rakyat dan bangsa Indonesia untuk menghirup udara kemerdekaan. Dalam upaya tersebut mereka menawarkan beberapa konsep yang kerap kali berhadap-hadapan (bertentangan). Di antara dispute tersebut menyangkut masalah nasionalisme, ${ }^{2}$ dasar dan bentuk Negara (Negara Islam atau sekuler). ${ }^{3}$

Langkah antisipatif tersebut bergulir dengan dinamis sejak munculnya gejala kekalahan Jepang atas sekutu. Gejala tersebut sepertinya memberikan sinyal pada Jepang akan munculnya vacuum of power bila mereka tidak segera bertindak. Namun Nippon juga tidak mau begitu saja melepaskan Indonesia dari genggamannya. Sebagai langkah antisipatif, pemerintah Nippon memberikan kelonggaran kepada rakyat Indonesia untuk berpartisipasi dalam pemerintahan, 4 Hal trsebut dibuktikannya dengan digantikannya tampuk kepemimpinan Shumubu, 5 dari

\footnotetext{
Penjelasan selengkapnya mengenai hal tersebut dapat dilihat dalam Bakhtiar Efendi, Islam dan Negara: Transformasi Pemikiran da Praktek Politik di Indonesia, (Jakarta: Paramadina, 1998), hlm. 70. Bandingkan dengan Daliar Noor yang mengidentivikasikannya dengan golongan nasionalis netral agama dan nasionalis Islam. Daliar Noor, Gerakan Modern Islam di Indonesia 1900-1942, (Jakarta: LP3ES, 1996), hlm. 267-27I.

2 Carlton J.H. Hayees mendefinikan nasionalisme dengan a fusion of patriotism with a conciousness of nationality. Sedangkan patriotisme didefinisikan sebagai love of country. Lihat Carlton J.H. Hayees, Nasionalism: A Reigion, (New York: Mac Millan Company, 1960), h. 2. Lihat juga Elnes Gelner, Nation and Nationalism, New York: Cornel University Press, 1983), h. $1-5$.

3 Lihat komentar Supomo mengenai untung dan ruginya jika Indonesia menjadi Negara Islam, dalam B.J. Boland, The Struggle of Islam in Modern Indonesia, (Hague: Martinus Nijhoff, 1982), h.20.

${ }^{4}$ Lihat A. Syafi'i Ma'arif, Peta Bumi Intelektualisme Islam di Indonesia, diedit oleh Fauzi Rahman, (Bandung: Mizan, 1993), h. 188.

5 Shumubu adalah kantor Departemen Agama (sekarang: Kementerian Agama), atau semacam office for Native Affair pada masa pemerintahan Hindia Belanda.
} 
Kolonnil Horie kepada Prof. Hussien Djayaningrat, kemudian K.H. Hasyim Asy'ari yang pelaksana hariannya adalah K.H. Wahid Hasyim. ${ }^{6}$ Pendekatan semacam itu diambil oleh pemerintah Nippon -- menurut Harry J.Benda-dalam rangka Nippon's Islamic Grassroots Policy untuk melawan sekutu.

Sudah menjadi wacana publik bahwa suatu negara bisa berdiri dengan tegak dan kokoh jika dilandaskan pada dasar Negara yang mapan. Wacana inilah yang menjadi topik diskusi paling alot di kalangan tokoh-tokoh bangsa Indonesia baik kalangan Islam maupun nasionalis. Satu pihak menghendaki Islam sebagai ideologi bangsa dan memberlakukan hukum Islam di Indonesia, ${ }^{7}$ sementara pihak lain menghendaki merumuskan landasan Negara yang berwawasan kebangsaan agar tidak terjadi kecemburuan dan diskriminasi agama. Pada kenyataan selanjudnya lahirlah beberapa rumusan tentang dasar Negara yang antara lain adalah Piagam Jakarta dan Pancasila yang akhirnya dijadikan sebagai Dasar Negara Republik Indonesia.

Lahirnya Pancasila sebagai dasar Negara juga menimbulkan polemik di kalangan cendikiawan muslim Indonesia: apakah Pancasila sesuai dengan ajaran Islam, atau malah sebaliknya. Masalah pokok yang muncul adalah bagaimana memposisikan Islam dalam dasar negera, yang dalam hal ini adalah Pancasila.

\section{Islam dan Dasar Negara pada Masa pra Proklamasi Kemerdekaan}

Pada masa penghujung pendudukan Jepang, ketika pasang perang beralih dengan pegharapan memperoleh dukungan Indonesia untuk usaha perangnya, Jepang mengubah sikapnya

${ }^{6}$ Penjelasan selengkapnya dapat dilihat dalam Harry Julian Benda, The Cressent and The Rising Sun: Indonesian Islam under The Japanese Occupation, 1942-1945, (The Hague: W. Van Hoeve, 1958), h. 134.

7 Pandangan tersebut didasarkan padakenyataan bahwa mayoritas bangsa Indonesia beragama Islam, dan Islamic Law pernah diberlakukan di Nusantara bersama dengan hukum Adat. Lihat penjelasannya dalam B.J. Boland dan I. Farjon, Islam in Indonesia: A Bibliographycal Survey 1600-1942, with Post 1945 Addenda, (t.d). Lihat juga Michael R.J. Vatikiotis, Indonesian Politics under Soeharto, (London: Routledge, 1994), h. 120-121.

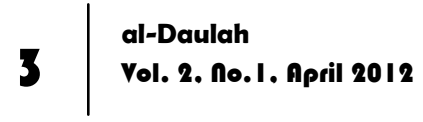


tehadap kaum nasionalis Indonesia, dengan memperkenalkan mereka mengambil sebagian yang lebih aktif dalam urusan Negara serta kebebasan bergerak yang lebih luas. Orang Indonesia kini diperkenalkan membentuk organisasi bersenjata sendiri. Di samping itu, pada 7 September 1944, Perdana Menteri Jepang, Koiso, menjanjikan Indonesia "merdeka kelak di kemudian hari". Pada 1 Maret 1945 janji ini diulangi kembali oleh Panglima Tertinggi Jepang dan sekaligus mengumumkan pembentukan Badan Penyelidik Usaha Persiapan Kemerdekaan Indonesia (BPUPKI). ${ }^{8}$

Rangkaian pertama sidang Badan Penyelidik berlangsung dari 29 Mei -1 Juni. Pada hari penutupan Soekarno menyampaikan pidato, yang di dalamnya diuraikan untuk pertama kali citacitanya tentang lima prinsip atau Pancasila yang menurut pendapatnya harus menjadi dasar Negara Indonesia merdeka. Penjelasan Soekarno secara terperinci dan perdebatan berikutnya tentang Pancasila sebagai dasar negara demikian menyinggung persoalan-persoalan pokok tentang konflik yang mendatang antara para pendukung Negara "sekuler" dan para pendukung Negara Islam. Soekarno, dalam pidatonya, mengusulkan nasionalisme Indonesia sebagai prinsip pertama, yang menjadikan dasar Negara Indonesia. Ia mengingatkan para pendengarnya, bahwa nasinalisme tidak dimaksudkan dibiarkan merosot menjadi chauvinism. Karena itu, diusulkannya internasionalisme atau kemanusiaan sebagai prinsip kedua.

Dalam menguraikan pandangannya tentang prinsip yang ketiga, yaitu demokrasi, Soekarno menolak gagasan bahwa Islam akan merupakan salah satu dasar Negara Indonesia. Dalam pandangannya dewan-dewan perwakilan adalah tempat yang layak untuk memperjuangkan cita-cita Islam. Maka ia menganjurkan pemimpin-pemimpin muslim yang hadir berusaha memperoleh mayoritas dalam bada-badan perwakilan ini, bila

${ }^{8}$ Harry J. Benda, The Cressent, h. 173 dan 184.

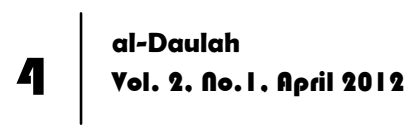


mereka menginginkan pemerintah Indonesia mengeluarkan peraturan-peraturan yang sesuai dengan hukum Islam. Ditambahkannya secara terus terang bahwa hanyalah bila $60 \% \mathrm{~s} / \mathrm{d}$ $90 \%$ wakil-wakil pilihan rakyat menghendaki konstitusi Islam baru terbukti bahwa Islam benar-benar dihayati di kalangan penduduk Indonesia dan bahwa penduduk Indonesia tidak hanya asal mengatakannya saja. Dalam pidatonya tanggal 1 Juni, pernyataan ini diulanginya kembali:

"Sebagai orang Islam, saya telah menganjurkan kepada umat Islam Indonesia supaya bekerja keras untuk mempropagandakan agama Islam sehebat-hebatnya dalam kalangan rakyat Indonesia, sehingga jika betul sebagian besar rakyat Indonesia itu jiwanya berkorban dengan api Islam, rohnya menyala-nyala dengan roh Islam, tidak boleh tidak, bukan saja presiden Republik Indonesia nanti orang Indonesia bahkan saya berkata tiap-tiap undangundang yang keluar dari badan perwakilan bercorak Islam pula." ${ }^{\prime 9}$

Dengan pernyataan ini Soekarno menghadapkan kenyataan kepada para pemimpin Islam bahwa walaupun mayoritas agama penduduk Indonesia kira-kira 80 - 90\% dari keseluruhannya adalah muslim, sebagian besar mereka agak lalai menjalankan kewajiban agamanya dan jelas lebih menyukai Negara "sekuler" ketimbang Negara Islam. Keadaan di Jawalah terutama yang dibayangkan Soekarno ketika menjelaskan pandangannya dengan mengatakan bahwa baginya adalah merupakan kebenaran yang objektif bahwa Islam sebenarnya belum dihayati di kalangan rakyat.

Demokrasi dengan sendirinya tidaklah cukup, kata Soekarno melanjutkan. Karena itu, prinsip keempat yang menjadi landasan Indonesia adalah keadilan soial atau kemakmuran. Tidak boleh ada kemiskinan dalam suatu negara Indonesia yang merdeka.

9 Muhammad Yamin, Naskah Persiapan UUD 1945, (Jakarta: Yayasan Prapanca, 1960), h. h. 380.

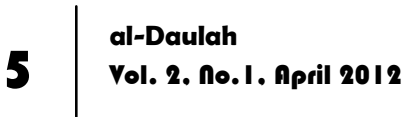


Sebagai prinsip terakhir yang diajukan Soekarno adalah ketuhanan. Rakyat Indonesia harus menjadi bangsa yang religious. Setiap orang Indonesia harus menyembah tuhannya sesuai dengan prinsip agamanya sendiri dan menghormati agama orang lain.

Dalam sidang pertama Badan Penyelidik Usaha Persiapan Kemerdekaan, cita-cita Islam juga ditolak oleh Mohammad Hatta dan Supomo (menteri kehakiman Indonesia yang pertama). Yang belakangan ini lebih luas menjabarkannya ketimbang Soekarno. Ketimbang menuju ke inti persoalannya dengan menunjukkan keengganan sebagai penduduk muslim untuk hidup sesuai syariat Islam dalam arti yang sesungguhnya. Ia meghindarkan persoalan yang dapat menyinggung perasaan tentang sejauh mana Islam diterima masyarakat Islam dan dengan menjelaskan alasan dan dengan contoh-contoh dari Negara-negara muslim seperti Mesir. Ia mengemukakan bahwa menerima Islam sebagai dasar Negara masyarakat pasti tidak berarti mengakhiri semua perbedaan ideologis. Dalam negeri-negeri seperti ini, menurut Supomo, perbedaan pendapat mungkin akan timbul mengenai bagaimana syariat Islam akan disesuaikan dengan perkembangan modern di dunia pada umumnya. Alasan lain yang dikemukakan Supomo ialah jika Islam diterima sebagai dasar Negara, Indonesia tidak mungkin menjadi Negara kesatuan untuk selama-lamanya. Pembentukan suatu Negara Islam akan berarti bahwa Negara mengedentisifikasi dirinya dengan bagian terbesar rakyat yang akan menimbulkan masalah minoritas. Walaupun suatu Negara belum tentu akan menjamin perlindungan kepentingan minoritas, demikian dilanjudkannya, kalangan minoritas sendiri tidak akan bisa mengedentisifikasikan diri dengan Negara. ${ }^{10}$

Pidato Soekarno pastilah mengakhiri pertentangan antara pembela dan penentang suatu Negara Islam pada akhir pendudukan Jepang. Pada sidang tanggal 22 Juni terbentuk panitia kecil, yang terdiri dari sembilan orang, untuk mempelajari

\footnotetext{
${ }^{10}$ Muhammad Yamin, Naskah Persiapan, h. I 16-117.
}

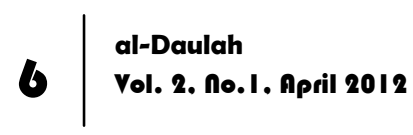


kedudukan Islam. Para pendukung Negara "sekuler" atau kaum nasionalis -- demikian Soekarno menyebut mereka sebulan kemudian dalam laporannya dalam rapat pleno Badan Penyelidik - diwakili 4 orang anggota : Mohammad Hatta, Muhammad Yamin, Subardjo dan Maramis. Dari kalangan Islam, Abdul Kahar Muzakkir, Wahid Hasyim, Agus Salim dan Abikusno yang turut serta. Soekarno sendiri bertindak sebagai ketua.

Panitia sembilan mencapai kompromi yang kelak dikenal sebagai Piagam Jakarta. Ini merupakan mukaddimah dalam konstitusi yang tampaknya dapat disetujui semua anggota panitia, "sekuler" maupun Islam. Mukaddimah ini memasukkan prinsipprinsip Pancasila yang diuraikan Soekarno pada awal Juni, walaupun sekarang dengan kata-kata yang sedikit berbeda. Tetapi ada perbedaan yang penting. Pertama, urutan kelima prinsip telah berubah. Ketuhanan, yang disebut Soekarno sebagai dasar kelima, sekarang menjadi pertama. Kedua, dan yang paling penting, perubahannya mengenai posisi Islam. Ketika Soekarno membahas ketuhanan sebagai salah satu dasar Pancasila, hal ini dilakukannya dengan menggunakan kata-kata yang umum, tanpa satu patah katapun secara khusus menyebut Islam. Sesungguhnya ia telah sempat menolak membuat ketentuan khusus untuk Islam dalam kerangka konstitusi untuk bakal republik. Ini kemudian berubah dalam Piagam Jakarta. Para anggota muslim dalam panitia sembilan mendesak adanya suatu ketentuan khusus untuk kalangan Muslim, dan mempengaruhi anggota-anggota lain untuk menyatakannya dengan bentuk lain. Karena itu, dalam Piagam Jakarta ketuhanan dinyatakan sebagai sila pertama yang menjadi landasan Republik, dan diluaskan dengan anak kalimat berikut: "dengan kewajiban melaksanakan syariat Islam bagi pemeluknya". ${ }^{11}$

Ketentuan ini, menurut Boland, yang termasuk orang pertama yang mengemukakan pentingnya Piagam Jakarta, dikenal sebagai

"' B.J. Boland, The Strugg/e, h.27.

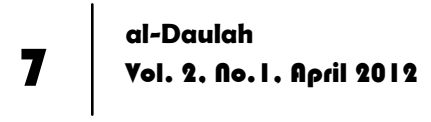


"ketujuh patah kata". Ini menimbulkan banyak polemik dalam tahun-tahun kemudian.

Pada 11 Juli dibentuklah tiga panitia kecil, satu di antaranya untuk menyusun konstitusi yang diketuai oleh Soekarno. Dari panitia sembilan terdahulu hanya dia, Maramis, Agus Salim, Subardjo, dan Wahid Hasyim yang turut serta. Panitia kecil ini mengadakan rapat pada tanggal 11 dan 13 Juli. Ketika mukaddimah konstitusi diajukan untuk dibicarakan, segera datang serangan dari Latuharhary yang mewakili golongan Kristen dari Maluku. Dia menyatakan keberatan terhadap anak kalimat dalam mukaddimah yang menetapkan bahwa para pemeluk Islam harus melaksanakan syari'at Islam. Hal ini dilakukannya, katanya, karena akibat yang mungkin akan ditimbulkannya bagi para pemeluk agama-agama lain, dan karena kesulitan yang mungkin timbul dalam hubungan hukum Islam dan hukum Adat. Dia disokong oleh Wongsonegoro dan Husein Djayadiningrat, yang keduanya mempunyai latar belakang Aristokrasi tradisional Jawa. Mereka menyatakan prihatin kalaukalau Piagam Jakarta diterima, akan mendorong fanatisme di pihak sebagian masyarakat Islam Indonesia.

Keberatan tersebut ditolak oleh Agus Salim dan Soekarno. Agus Salim mengemukakan argumentasi kata-kata yang agak lemah dasarnya bahwa "pertentangan antara hukum agama dan hukum adat bukanlah masalah baru, dan pada umumnya telah teratasi". Bahkan Soekarno menegaskan, Piagam Jakarta merupakan suatu kompromi yang telah dicapai dengan susah payah, karena begitu harus dibiarkan utuh. ${ }^{12}$ Dia berhasil meyakinkan para anggota yang lain untuk menghentikan pembicaraan tentang mukaddimah dan beralih pada pembahasan konstitusi. Akan tetapi ia tidak dapat mencegah ketika persoalan itu muncul kembali pada saat menbahas beberapa pasal konstitusi.

12 Safroedin Bahar dkk., Risalah Sidang Badan Penyelidik Usaha-usaha Persiapan Kemerdekaan Indonesia, Panitia Persiapan Kemerdekaan Indonesia, 28 Mei 1945 - 22 Agustus 1945, (Jakarta: Sekretariat Negara RI, 1995). 
Kali ini serangan datang dari kalangan muslim, yang diwakili oleh Wahid Hasyim. Amandemen pertama yang diajukannya adalah memasukkan dalam konstitusi suatu ketentuan yang menyatakan, hanyalah orang-orang Islam yang dapat memenuhi syarat untuk menjadi presiden atau wakil presiden. Dan yang kedua menyangkut dimasukkannya secara formal dalam konstitusi bahwa Islam harus menjadi agama Negara.

Usulan-usulan Wahid Hasyim disokong oleh wakil Islam lainnya dalam panitia kecil, yakni Sukiman, namun juga sekaligus ditentang oleh Agus Salim, Wongsonegoro, dan Husein Djayadiningrat. Yang pertama menyatakan bahwa diterimanya usulan amandemen Wahid Hasyim akan dapat membahayakan kompromi yang telah dicapai dalam mukaddimah. Dalam perdebatan singkat setelah usulan-usulan Wahid Hasyim, Wongsonegoro berusaha mencegak anak kalimat tentang pelaksanaan syari'at Islam. Singkatnya, pada Juli 1945, perhatian sepenuhnya dikuasai perdebatan tentang dimasukkannya atau tidak ketentuan bagi kaum muslim untuk melaksanakan syari'at Islam dalam mukaddimah.

Dalam rapat tanggal 14 Juli, perhatian terpusat lagi pada mukaddimah konstitusi. Pembahasan serius tentang hal ini muncul setelah salah seorang pembela bentuk Islam yang keras, $\mathrm{Ki}$ Bagus Hadikusumo, mengusulkan pencoretan kata-kata "pemeluk-pemeluk Islam" dalam anak kalimat "dengan kewajiban melaksanakan syari'at Islam bagi pemeluk-pemeluknya". Tentu saja usulan ini sama sekali tidak dapat diterima seperti sebelumnya. Soekarno berbicara kembali menghendaki teks anak kalimat dipertahankan, serta mengemukakan, Piagam Jakarta adalah suatu hasil kompromi, dan seperti juga setiap kompromi lainnya, maka letak pesroalannya sesungguhnya adalah pada kesediaan untuk sama-sama mengalah. ${ }^{13}$ 
Keesokan paginya konstitusi dengan pasal-pasalnya diajukan untuk dibicarakan, dengan penjelasan terlebih dahulu dari Soekarno dan Supomo. Tidak ada hal yang baru yang dikatakan Soekarno, dan tidak banyak yang menyimpang dari pidatonya pada 1 Juni. Supomo sekali lagi memperingatkan para anggota Badan Penyelidik agar tidak terpecah mengenai kedudukan Islam, dan agar mematuhi Piagam Jakarta.

Supomo sungguh menyadari ditentangnya anak kalimat ini dan adanya kecemasan terhadap dominasi Islam. Tapi diusahakannya meyakinkan rapat, bahwa kecemasan yang demikian tanpa dasar mengingat anak kalimat kedua pasal ini menjamin kebebasan beragama dan kebebasan bagi setiap warga Negara masing-masing untuk melakukan ibadat menurut agama dan kepercayaannya masing-masing. ${ }^{14}$

Sangat diragukan apakah alasan Supomo itu berkesan bagi para pendengarnya. Supomo dengan jelas hanya menunjukkan kata-katanya pada kalangan bukan muslim dalam usahanya meyakinkan para penentang Piagam Jakarta, walaupun pada kenyataannya, sepetri yang dikemukakan di atas, penentangan yang pokok datangnya dari kalangan Islam ( walaupun penentangan bukan muslim mungkin menambah pertentangan ). Mungkin pada waktu itu tidak dapat diramalkannya bahwa sebagian besar perlawanan akan datang dari kalangan muslim.

Dalam pembicaran selanjutnya, ketika lagi-lagi rapat menyinggung kedudukan Islam, adalah Muhammad Yamin yang memulai kembali mengecam naskah konstitusi, karena tidak sepenuhnya mencerminkan semangat mukaddimah dalam pasalpasalnya. Umpamanya mengenai kedudukan Islam, Muhammad Yamin meminta sepenuhnya agar diadakan kementerian agama untuk menaggulangi urusan-urusan Islam yang khas, seperti perawatan masjid-masjid, demikian juga untuk mendirikan Mahkamah Islam Tinggi. Menurutnya, Mahkamah Agung 
seharusnya tidak membatasi diri pada pelaksanaan peradilan, tetapi seyogyanya bertanggung Jawab juga untuk menjamin bahwa undang-undang yang dibuat parlemen tidak bertentangan dengan konstitusi hukum adat dan hukum Islam. Tampaknya rapat tidak banyak memberikan perhatian pada saran Yamin.

Pada sidang malam tanggal 15 Juli, lagi-lagi Ki Bagus Hadikusumo berusaha kembali membuka pendebatan tentang Islam. Ki Bagus lima kali mengatakan bahwa dia tidak mengerti anak kalimat "dengan kewajiban menjalankan syari'at Islam bagi pemeluk-pemeluknya", dan ditanyakannya apa artinya. Pertanyaan ini dijawab ketua rapat, Radjiman Widiodiningrat, yang sependapat bahwa ini adalah pertanyaan yang sulit dan tiap kali Ki Bagus mendesak agar diberi penjelasan, disahutinya dengan menyatakan bahwa masalah itu telah diselesaikan dan seyogyanya perdebatan-perdebatan itu tidak dimulai lagi. Pada akhirnya Ki Bagus menyatakan terpaksa menjelaskan bahwa ia benar-benar tidak mengerti. Ki Bagus menyatakan terpaksa menyerahkan persoalannya begitu saja. Ketika setiap kali ia berusaha untuk meminta penjelasan, dan berupaya menguraikan pandangannya, selalu saja ditanggapi bahwa hal itu telah disepakati sebelumnya secara bulat. Dia disuruh berhenti oleh apa yang dilukiskannya sebagai perintah Soekarno dan Hatta, yang katanya berteriak "cukup, cukup !", sebelum ia mendapat kesempatan bicara. ${ }^{15}$

Pemimpin-pemimpin Islam dan "sekuler" yang ikut serta penyusun Piagam Jakarta, memiliki hasrat yang sangat kuat untuk menyelamatkan Piagam Jakarta, dan melupakan bahwa ada orangorang lain yang keberatan terhadap cara merumuskan posisi sosial Islam secara konstitusional. Mereka inilah barang kali yang telah memaksa Ki Bagus Hadikusumo menghentikan penentangannya karena terus menerus ngotot. Bagaimanapun mereka berhasil

${ }^{15}$ Muhammad Yamin, Naskah Persiapan, 37I-374.

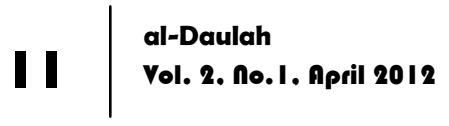


membujuk Ki Bagus -- entah bagaimana -- untuk tidak lagi mengajukan pertanyaan selanjudnya.

Dalam rapat selanjudnya, walaupun ada kompromi baru mengenai jaminan Negara terhadap kemerdekaan tiap-tiap penduduk untuk memeluk agamanya sendiri dan beribadah menurut agama dan kepercayaannya, serangan kalangan Islam terhadap rancangan konstitusi berlanjut karena menurut mereka tidak diberikan tempat yang layak bagi Islam dalam masyarakat. Persoalan yang mereka gunakan sekarang untuk menyalurkan kekecewaan mereka adalah syarat-syarat resmi bagi pencalonan presiden. Pembicaraan baru, dan yang kadang-kadang berlangsung sangat sengit ini, dicetuskan Pratalykrama, yang menanyakan apakah konstitusi tidak harus memuat ketentuan bahwa presiden harus sedikit-dikitnya berusia 40 tahun, orang Indonesia asli, dan beragama Islam. Saran ini ditolak Agus Salim dengan menyatakan bahwa ketentuan dalam konstitusi yang menyatakan bahwa presiden harus beragama Islam akan membahayakan kompromi Piagam Jakarta. Pilihan presiden menurutnya seharusnya diserahkan kepada kongres yang diberi kekuasaan oleh rancangan konstitusi untuk memilih presiden dan wakilnya. Dikemukakannya, suatu ketentuan tertulis bahwa Indonesia harus mempunyai seorang presiden yang beragama Islam hanya akan menumbuhkan soal-soal baru lainnya.

Pada tanggal 15 Juli ini juga, Masykur (Masyumi ), seorang kiai dari Jawa Timur mengusulkan dua jalan untuk menyelesaikan persoalan. Pertama. dengan menghilangkan pernyataan kewajiban bagi kaum muslimin untuk melaksanakan syariat Islam, tetapi menggantikannya dengan ketentuan bahwa agama resmi RI haruslah Islam. Kedua, dengan menentukan bahwa presiden Indonesia harus seorang muslim. Jelas, Supomo dan Radjiman tidak mampu menghadapi keadaan. Yang akhir ini meminta Soekarno menjawab dengan harapan wibawa Soekarno mungkin cukup besar untuk mengubah oposisi para anggota Islam. Lalu Soekarnopun melakukan hal itu. Karena Soekarno terus mendesak 
Masykur agar menyetujui dan menerima saja, Abdul Kahar Muzakkir akhirnya turut campur. Dengan menyatakan berbicara atas nama pemimpin Islam yang hadir, dengan marah ia mengusulkan mencoret setiap referensi kepada Islam dalam mukaddimah, dalam konstitusi dan dalam pernyataan kemerdekaaan yang juga disusun Badan Penyelidik. Radjiman Widiodiningrat mendesak agar diadakan voting. Tetepi, para anggota muslim dari Badan Penyelidik dengan tegas menjawab tidak mungkin mengadakan voting tentang agama. Seluruh kompromi yang telah dicapai dengan susah payah dalam keadaan bahaya.

Ahmad Sanusi menekankan, ada dua alternatif yang tinggal, yaitu menerima usul-usul Masykur atau menolaknya dan mengikuti saran Abdul Kahar Muzakkir untuk mencoret semua referensi kepada Islam. Dia disokong Ki Bagus Hadikosumo, yang mendesak agar di sini dan sekaranglah diputuskan apakah Negara Indonesia akan menjadi Negara " sekuler " atau Islam. Bila mayoritas menolok Negara Islam, maka Negara harus netral mengenai agama. Tetepi dalam keadaan bagaimanapun, janganlah konstitusi memuat hanya sesuatu yang samar dan dangkal tentang Islam. Ini akan menimbulkan kesan yang buruk pada masyarakat Islam, yang sungguh-sungguh tahu apa yang menjadi persoalannya.

Sesudah rapat ditutup, wakil-wakil dari golongan Islam maupun bukan Islam mengadakan pertemuan tidak resmi atas prakarsa Soekarno untuk berusaha mencari jalan keluar dari kebuntuan. Dari rapat inilah tentunya berasal usulan apa yang dibuat Soekarno pada hari berikutnya dengan meminta pengorbanan para anggota bukan Islam, karena "ada keagungan dalam pengorbanan ". Soekarno meminta untuk memasukkan dalam konstitusi ketentuan bahwa presiden harus seorang Indonesia asli dan seorang muslim, dan membiarkan pasal tentang agama, termasuk ketentuan bahwa umat muslim harus menjalankan syariat Islam tidak berubah. Setelah melalui 
perdebatan, akhirnya mayoritas amandemen-amandemen yang disarankan Soekarno diterima secara bulat.

\section{Islam dan Dasar Negara Masa Pasca Proklamasi Kemerdekaan}

Seperti apa yang kemudian menjadi kenyataan, semua pembicaraan menjadi sia-sia, dan konstitusi yang disusun Badan Penyelidik tidak pernah diberlakukan. Indonesia merdeka sesungguhnya menjadi Negara " sekuler " yang di dalamnya tidak ada persoalan mengenai persoalan hukum bagi umat muslim untuk menjalankan syariat Islam.

Pertanyaan yang mungkin muncul ialah mengapa konstitusi yang berdasarkan Islam dan sudah disepakati oleh Badan Penyelidik tidak pernah diberlakukan. Sebagai salah satu Jawabannya bahwa menurut fakta sejarah, sehari setelah proklamasi kemerdekaan (18 agustus ), panitia kecil (sebagian dari anggota BPUPKI ) yang dikenal dengan Panitia Persiapan Kemerdekaan Indonesia (PPKI) mengadakan rapat, ${ }^{16}$ rapat ini dipimpin oleh ketua dan wakilnya, Soekarno dan Hatta. Agenda utama rapat ini adalah membicarakan perubahan Preambul (berasal dari Piagam Jakarta) dan batang tubuh Undang-Undang Dasar. ${ }^{17}$ Hatta yang dipersilakan untuk menyampaikan empat usul perubahan yaitu 1- Kata "mukaddimah" diganti dengan kata "pembukaan" 2- Dalam Preambul (Piagam Jakarta), anak kalimat "berdasarkan kepada ketuhanan, dengan kewajiban menjalankan syariat Islam bagi pemeluk-pemeluknya" diubah menjadi "berdasarkan atas ketuhanan yang maha esa" 3- Pasal b ayat1, "presiden ialah orang Indonesia asli dan beragama Islam" dicoret. 4- Sejalan dengan perubahan nomor dua, maka pasal 29 ayat1 menjadi "Negara berdasar atas ketuhanan yang maha esa", sebagai tanda pengganti "Negara bedrasarkan atas ketuhanan,

\footnotetext{
${ }^{16}$ Muhammad Yamin, Naskah Persiapan, h. 399.v

17 Muhammad Yamin, Naskah Persiapan, h. 400.
} 
dengan kewajiban menjalankan syariat Islam bagi pemelukpemeluknya". ${ }^{18}$

Pada waktu itu anggota Panitia Persiapan yang mengikuti rapat menyetujui secara bulat perubahan Preambul dan batang tubuh Undang-Undang Dasar ini. Kemudian Preambul dan batang tubuh Undang-Undang Dasar yang mengalami perubahan tersebut pada akhirnya dikenal sebagai Undang-Undang Dasar $1945 . .^{19}$

Pertanyaan sejarah pun muncul. Apa sebab Panitia Persiapan menyetujui perubahan Preambul yang menyebabkan dirubahnya batang tubuh Undang-Undang Dasar sehimgga dasar Negara bukan Islam. Kekuatan apa yang mendorong sehingga prubahan itu terjadi. Mengapa Soekarno, yang dalam sidang-sidang Badan Penyelidik mempertahankan Preambul (Piagam Jakarta) kemudian memelopori usaha untuk mengubahnya. ${ }^{20}$

Hatta mengemukakan alasan yang berkaitan dengan pertanyaan-pertanyaan di atas. Menurut Hatta bahwa pada hari proklamasi sorenya, seorang opsir Angkatan Laut Jepang datang menemuinya. Opsir itu mengatakan bahwa wakil-wakil Protestan dan Katolik keberatan atas anak kalimat atau klausul Islami dalam Preambul yang berbunyi "ketuhanan dengan kewajiban menjalankan syariat Islam bagi pemeluk-pemeluknya". Mereka menganggap klausum Islami ini diskriminatif terhadap golongan minoritas. Kemudian Hatta berjanji akan menyampaikan masalah itu dalam rapat Panitia Persiapan keesokan harinya (sehari setelah proklamasi). ${ }^{21}$

Paginya, sehari setelah proklamasi, Hatta mengajak Ki Bagus Hadikusumo, Wahid Hasyim, Kasman Singodimejo dan Teuku

\footnotetext{
18 Muhammad Yamin, Naskah Persiapan, h. 402.

${ }^{19}$ Endang Saifuddin Anshari, Piagam Jakarta 22 Juni 1945, (Jakarta: Gema Insani Press, 1997), h. 48.

20 Pertanyaan-pertanyaan tersebut dimajukan oleh Prawoto Mangkusasmito. Lihat Prawoto Mangkusasmito, Pertumbuhan Historis Rumus Dasar Negara dan Sebuah Proyeksi, (Jakarta: Hudaya, 1970, h. 21.

${ }^{21}$ Prawoto Mangkusasmito, Pertumbuhan Historis, h. 51.
}

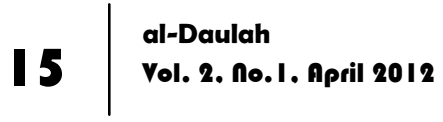


Hasan dari Sumatera untuk mengadakan suatu pertemuan pendahuluan guna membicarakan usul opsir Angkatan Laut Jepang itu. Untuk menghindari perpecahan sebagai bangsa, mereka sepakat menghilangkan klausul Islami yang menusuk hati golongan Kristen dan Protestan tersebut dan menggantinya dengan "ketuhanan yang maha esa". ${ }^{22}$

Ada beberapa poin dalam keterangan Hatta ini yang layak diperhatikan. Pertama, konsensus nasional tentang Preambul yang sudah dicapai dengan susah payah dalam Badan Penyelidik dimentahkan oleh usul seorang opsir Angkatan Laut Jepang (yang namanya tidak diingat oleh Hatta). Kedua, dari keterangan Hatta dapat diketahui bahwa keberatan opsir itu yang mengatasnamakan golongan Katolik dan Protestan atas klausul Islami dalam Preambul saja, ia tidak menyinggung batang tubuh Undang-Undang Dasar. Namun yang dicoret oleh Panitia Persiapan bukan hanya klausul Islami yang terdapat dalam Preambul, melainkan juga kalusul Islami dalam batang tubuh Undang-Undang Dasar. Ketiga, alasan Hatta untuk mencoret klausul Islami dalam Preambul dan dalam batang tubuh UndangUndang Dasar supaya tidak merusak perasaan golongan Kristen dan Protestan dan supaya bangsa Indonesia yang baru merdeka tidak terpecah belah. ${ }^{23}$

Kemudian menarik untuk dicer mati adalah perimbangan kekuatan antara nasiolis Islam (yang diwakili Ki Bagus, Wahid Hasyim, Kasman dan Teuku Hasan) dan nasionalis "sekuler" (yang di wakili Hatta) yang diundang oleh Hatta dalam pertemuan pendahuluan sebelum rapat Panitia Persiapan. Sebagaimana diketahui bahwa pertemuan pendahuluan itu menghasilkan perubahan dalam Preambul dan disetujui oleh Panitia Persiapan dalam rapatnya, tampak perimbangan kekuatan ini menguntungkan golongan Islam. Tapi Wahid Hasyim tidak hadir dalam pertemuan pendahuluan ini karena ia ke Jawa Timur,

22 Mohammad Hatta, Sekitar Proklamasi 17 Agustus 1945, (Jakarta: Tintamas, 1969), h.57-59.

${ }^{23}$ Endang Saifuddin Anshari, Piagam Jakarta, h. 52. 
Kasman tidak banyak tahu karena ia anggota baru Panitia Persiapan dan menerima undangan rapat pada pagi harinya, Teuku Hasan mendukung perubahan Preambul karena ia bukan kelompok nasionalis Islam. Maka sebenarnya wakil Islam yang bertanggung Jawab atas perubahan itu hanya Ki Bagus. ${ }^{24}$

Analisis lain yang muncul mengapa tidak ada kesinambungan antara tindakan panitia kecil (sembilan orang) penandatanganan Preambul (Piagam Jakarta) yang asli dan putusan Panitia Persiapan. Tidak lain karena hanya empat orang penanda tangan Piagam Jakarta yang jadi anggota Panitia Persiapan yaitu Soekarno, Hatta, Soebardjo, dan Wahid Hasyim, lima orang lainnya yaitu Yamin, Maramis, Agus Salim, Abikoesno, dan Kahar Muzakkir (tiga yang terakhir nasionalis Islam) tidak diundang menghadiri rapat Panitia Persiapan. Kemudian hanya satu orang nasionalis Islam yaitu Wahid Hasyim yang jadi angota Panitia Persiapan dan dia tidak hadir dalam rapat tersebut. Jadi hanya tiga orang penanda tangan Piagam Jakarta, yaitu Soekarno, Hatta, dan Soebardjo (nasionalis "sekuler"), yang terlibat dalam proses pengubahan Preambul (Piagam Jakarta) dan batang tubuh Undang-Undang Dasar pada rapat Panitia Persiapan di hari kedua pasca kemerdekaan. Tidak seorang pun dari nasionalis Islam yang hadir dalam rapat tersebut. ${ }^{25}$

Kalau ditelaah secara lebih mendalam lagi, kesepakatan pengubahan Preambul (Piagam Jakarta) dan batang tubuh Undang-Undang Dasar yang dicapai Panitia Persiapan Kemerdekaan Indonesia (PPKI) yang mengantarkan Indonesia berdasarkan Pancasila dan UUD 1945 bukan tanpa alasan dan pertimbangan. Konsensus tersebut dicapai setelah melalui proses musyawarah dan berbagai pertimbangan serta alasan.

\footnotetext{
${ }^{24}$ Prawoto Mangkusasmito, Pertumbuhan Historis, h. 38-39. Kasman tidak menguasai masalah, karena bukan anggota Badan Penyelidik, dan Ki Bagus Hadikusumo bukan penandatangan Piagam Jakarta.

${ }^{25}$ Endang Saifuddin Anshari, Piagam Jakarta, h. 53.
} 
Kalangan tokoh muslim yang menjadi anggota PPKI menerima Pancasila sebagai dasar Negara dengan kesadaran penuh bahwa Pancasila sama sekali tidak bertentangan dengan Islam, prinsip-prinsip atau asas-asas yang terdapat dalam Pancasila tidak bertentangan dengan ajaran Islam. Kelima asas yang terdapat dalam Pancasila mencerminkan suatu sikap yang Islami. Pencerminan nilai-nilai Pancasila juga merespon nilai-niali akhlak yang mulia dari ajaran Islam. Dan yang paling melegakan kalangah tokoh muslim adalah tercantumnya sila pertama dari Pancasila, "ketuhanan yang maha esa", yang merupakan dasar dari semua sila yang terdapat dalam Pancasila, sangat sesuai dengan ajaran atau akidah Islam. Dengan demikian, Negara Indonesia yang baru diproklamasikan merupakan sebuah Negara yang berketuhanan, dalam hal ini adalah tuhan yang esa. Suatu prinsip yang diperpegangi dalam Pancasila adalah bahwa semua sila yang terdapat dalam Pancasila harus sesuai atau berdasarkan sila pertama, ketuhanan yang maha esa. Dengan kata lain, segala tindak tanduk, prilaku, dan watak dari bangsa Indonesia harus berdasarkan ketuhanan yang maha esa, yang dalam hal ini dapat dipahami sebagai prilaku yang mencerminkan tauhit yang benar.

Pecahnya tokoh-tokoh Islam yang tergabung dalam PPKI menjadi dua kubu sebenarnya lebih disebabkan oleh visi atau cara pandang mereka yang berbeda. Satu kelompok menghendaki dipakainya Islam sebagai dasar Negara, maksudnya secara simbolis Negara Indonesia berdasarkan Islam. Dengan demikian, Islam harus di tegaskan -- secara simbolis -- sebagai dasar Negara. Sementara itu, kelompok yang lain menghendaki ajaran Islam diakomodir dalam dasar Negara, walaupun Islam tidak disebut secara simbolis, apapun nama dari dasar Negara tersebut, yang penting secara substansial mencerminkan ajaran-ajaran Islam. Dengan kata lain, secara substansial, dasar Negara itu sesuai dengan ajaran Islam. Dalam pandangan mereka, secara subtansial, Pancasila tidak bertentangan, bahkan sejalan dengan ajaran-ajaran Islam. 
Kenyataan di atas memberikan gambaran perihal jiwa besar para elit atau tokoh muslim yang tergabung dalam keanggotan PPKI dengan menerima Pancasila sebagai dasar Negara Republik Indonesia yang baru saja diproklamasikan. Bagi mereka, kepentingan bangsa dan Negara di atas segala-galanya. Keutuhan bangsa dan Negara harus tetap diperhatikan dengan selalu menjaga kesatuan dan persatuan bangsa. Kepentingan seperti itu harus selalu dikedepankan dari pada kepentingan golongan, apalagi interes pribadi. Para pendiri republik ini telah memberikan teladan yang sebaik-baiknya untuk dikenang dan dicontoh oleh generasi berikutnya. Dengan tetap berkiblat pada garis perjuangan mereka, keutuhan bangsa ini, dengan Pancasila sebagai dasar Negara, akan tetap terjaga sampai kapanpun.

\section{Penutup}

Dari uraian di atas dapat ditarik kesimpulan bahwa diterimanya Pancasila sebagai dasar Negara bukan merupakan sesuatu yang taken for granted, melainkan dicapai melalui proses diskusi yang panjang sejak pra kemerdekaan hingga pasca kemerdekaan, dalam hal ini, terdapat dua kubu (kelompok) yang memiliki visi atau pandangan yang berbeda antara satu dengan yang lainnya mengenai dasar Negara dari Negara yang sebentar lagi akan diproklamirkan. Pertama, adalah golongan nasionalis "sekuler" yang memandang bahwa Negara yang akan didirikan (Republik Indonesia) harus berdasarkan kebangsaan, bukan Islam, dengan alasan tidak seluruh rakyat Indonesia beragama Islam. Sementara itu, golongan kedua, golongan nasionalis berpandangan bahwa dasar Negara dari bangsa Indonesia harus Islam, dengan alasan bahwa mayoritas rakyat Indonesia beragama Islam. Walaupun mayoritas tim perumus yang tergabung dalam keanggotaan Panitia Persiapan Kemerdekaan Indonesia (PPKI) adalah muslim, namun pada akhirnya dicapai kesepakatan dasar Negara republik Indonesia adalah Pancasila. 
Para tokoh muslim yang ikut membidani berdirinya republik ini dengan kebesaran jiwanya menerima Pancasila sebagai dasar negera Republik Indonesia dengan beberapa alasan dan pertimbangan. Mereka beralasan bahwa Pancasila tidak bertentangan dengan Islam, bahkan pencerminan dari nilai-nilai Pancasila sesuai dan sejalan dengan ajaran agama Islam. Kenyataan tersebut meggambarkan ajaran-ajaran Islam secara substansial terakomodir dalam Pancasila. Walaupun secara simbolis Islam tidak dipakai (disebut) sebagai dasar negara, namun secara substansial prinsip-prinsip yang terdapat dalam Pancasila sudah mencerminkan nilai-nilai yang Islami. Dengan demikian, tidak ada alasan bagi mereka untuk menolak Pancasila sebagai dasar Negara republik Indonesia.

\section{Daftar Pustaka}

A. Syafi'i Ma'arif, Peta Bumi Intelaktualisme Islam di Indonesia diedit oleh Fauzi Rahman, Mizan , Bandung, 1993

B.J. boland, The Stuggle of Islam in Modern Indonesia, Martinus Nijhoff, The Hague,1982

-------, dan I. farjon, Islam in Indonesia : A bibliographical Survey 1600-1942 with Post 1945 Addenda, t.d

Bakhtiar Efendi, Islam dan Negara : Transformasi Pemikiran dan Praktek Politik di Indonesia, Paramadina, Jakarta, 1998.

Dealiar noor, Gerakan Modern Islam di Indonesia 1900-1942, LP3ES, Jakarta, 1996.

Elnes Gelner, Nation and Nationalism, : Cornel University Press, New York, 1983.

Endang Saifuddin Anshari, Piagam Jakarta 22 Juni 1945, Gema Insani Press, Jakarta, 1997.

Harry J. Benda, The Cressent and The Rising Sun : Indonesia Islam under the Japanese Occupation, 1942-1945 ,W. Van Houve, The Hague, 1958. 
J. H. Heyes, Nasionalism : A Religion: Mac Millan Company,. New york, 1960.

Michael R.J. Vatikiotis, Indonesian Politics under Soeharto, London, Routledge, 1994.

Mohammad Hatta, Sekitar Proklamasi 17 Agustus 1945, Tintamas, Jakarta, 1969

Muhammad Yamin, Naskah Persiapan UUD 1945, Yayasan Prapanca, 1960.

Prawoto Mangkusasmito, Pertumbuhan Historis Rumus Dasar Negara dan Sebuah Proyeksi, Hudaya, Jakarta,1970

Safroedin Bahar dkk, Risalah Sidang Badan Penyelidik Usaha-usaha Persiapan Kemerdekaan Indonesia, Panitia Persiapan Indonesia, 28 Mei 1945-22 Agustus 1945, Sekretariat Negeri RI,Jakarta, 1995. 